\title{
Water runoff from road surface in mountain forests
}

\author{
Janusz Gołąb \\ Department of Forest Engineering \\ Faculty of Forestry, University of Agriculture in Kraków \\ Al. 29-listopada 46, 31-425 Kraków \\ e-mail: rlgolab@cyf-kr.edu.pl
}

\begin{abstract}
Forest roads are treeless strips of land without any natural cover, appropriately shaped in a longitudinal and transverse direction, along which traffic is possible. Road embankments and surfaces are made of proper materials, with the preservation of technological requirements and particular attention to the density of subbases in the road construction. Surface water runoff occurs on all roads as a result of rainfall, because material density of the surface hinders or blocks the infiltration and the road gradient causes the water movement. Precipitation intensity and ground filtration capacity determine the runoff quantity. In forest areas, the surface runoff basically occurs on road surfaces and timber depots, while outside those sites, it rarely occurs in natural and not devastated areas. The paper presents the results of measurements of the surface-runoff intensity from forest dirt roads along several surveyed sections. Some sections were characterised by a high escarpment of the excavation and cross-cut canal for subsurface runoff. The unit intensity from measurement sessions of various precipitation levels was presented, as well as those from the period of snow cover melting. Measurements were taken every 15 minutes. On the basis of these measurements, simulation calculations of the amount of water were performed assuming the homogeneity of the area, the road network and precipitation characteristics, which can occur in the form of surface runoff on forest roads with similar characteristics, in the area of 100 ha, with the road network density of $15 \mathrm{~m} \cdot \mathrm{ha}^{-1}$ and $25 \mathrm{~m} \cdot \mathrm{ha}^{-1}$, during the precipitation lasting $3 \mathrm{~h}$. These values were referred to the total water quantity from such precipitation and compared with the standard water consumption by an average consumer.
\end{abstract}

Key words: runoff quantity, simulation, forest road network, road trench, slope drainage.

\section{Introduction}

Water, during its circulation in the hydrological cycle, reaches surface area in the form of the precipitation. When limiting the examination to precipitation liquid form, it can be stated that after entering area (land) surface, water either soaks into the ground or remains on its surface. This depends on two factors: ground filtration ability and precipitation intensity. Filtration ability strongly depends on ground structure that is from mutual grain and particle arrangement (Bochenek 2002), but also on condition of ground profile saturation with water from previous precipitation. Natural grounds with stable plant cover, e.g. forest grounds are characterised by relatively high porosity and as a result they can soak high amounts of water coming from precipitation. In the case of anthropogenically compacted soil, the structure and porosity are changed, which also changes conditions of water movement in the ground. Then such situation can take place that not the whole precipitation quantity, which has reached surface area, can be soaked by land (Wemple \& Jones 2003). This excess amount creates surface runoff on sloping surfaces as a result of gravitational force. Differences in filtration capacity in various grounds are provided by Gil (1990, after Słupik 1972): in abandoned agricultural soil $-90 \mathrm{~mm} \cdot \mathrm{min}^{-1}$, in ploughed soil $-1.2 \mathrm{~mm} \cdot \mathrm{min}^{-1}$, which can be compared with filtration capacity in ground surface of a slope road with high quantity of a natural structure: $0.00 \div 0.05 \mathrm{~mm} \cdot \mathrm{min}^{-1}$ (Gołąb et al. 2006). 
Table 1. The quantity of surface runoff in the forest areas of the Tatra Mountains (Midriak 1990)

\begin{tabular}{|c|c|cc|}
\hline Forest area & $\begin{array}{c}\text { Description } \\
\text { (height above sea level, fall, exposition) }\end{array}$ & Quantity of surface runoff \\
\hline Soil without plant cover (on storage area) & $1365 \mathrm{~m}$ above sea level, 18, $\mathrm{SSE}$ & $\begin{array}{c}312023 \\
0.00000099\end{array}$ & $\begin{array}{c}{\left[\mathrm{dm}^{3} \cdot \mathrm{ha}^{-1} \cdot \mathrm{year}^{-1}\right]} \\
{\left[\mathrm{dm}^{3} \cdot \mathrm{m}^{-2} \cdot \mathrm{s}^{-1}\right]}\end{array}$ \\
\hline Young fir tree & $1300 \mathrm{~m}$ above sea level, $8-16^{\circ}, \mathrm{NNE}$ & $\begin{array}{c}29287 \\
0.00000009\end{array}$ & $\begin{array}{c}{\left[\mathrm{dm}^{3} \cdot \mathrm{ha}^{-1} \cdot \mathrm{year}^{-1}\right]} \\
{\left[\mathrm{dm}^{3} \cdot \mathrm{m}^{-2} \cdot \mathrm{s}^{-1}\right]}\end{array}$ \\
\hline Fir forest stand of $100-150$ years old & $1343 \mathrm{~m}$ above sea level, 28, $\mathrm{N}$ & $\begin{array}{c}174823 \\
0.00000055\end{array}$ & $\begin{array}{c}{\left[\mathrm{dm}^{3} \cdot \mathrm{ha}^{-1} \cdot \mathrm{year}^{-1}\right]} \\
{\left[\mathrm{dm}^{3} \cdot \mathrm{m}^{-2} \cdot \mathrm{s}^{-1}\right]}\end{array}$ \\
\hline
\end{tabular}

Surface runoff is rarely observed in forested areas with undevastated, natural soil and plant cover. It is formed only after heavy precipitation on steep slopes covered with soil of low thickness level or in the case of ground saturation as a result of earlier precipitation (Kosturkiewicz \& Szafrański 1983). The quantity of surface runoff observed in the Tatra mountains are provided by Midriak (1990) (Table 1).

Other study, conducted by Słupik (1972), provide information about the quantity of surface runoff measured in the forest: $100 \mathrm{l} \cdot \mathrm{ha}^{-1} \cdot \mathrm{min}^{-1}\left(0.000167 \mathrm{dm}^{3} \cdot \mathrm{m}^{-2} \cdot \mathrm{s}^{-1}\right)$ during heavy precipitation $60-90 \mathrm{~mm}$, lasting for 1-2 hours.

Water in surface runoff omits a very important phase of water circulation in nature, namely the subsurface retention phase (Gołąb 2004), whose result are high stream levels after heavy precipitation and a threat of flood. The next outcomes were low ground water levels and the lack of water for broadly understood consumption. Therefore, the key factor in occurring of the surface runoff is surface area feature, just after precipitation intensity, which can be named as tightness of this surface and its fall. Water flowing in the form of surface runoff from the catchment area, very quickly reaches the stream dehydrating the valley and becomes unavailable for the valley ecosystem. Gradkowski (2011) states that surface runoff in areas, out of a forest or a city, constitute about $20 \%$ of precipitation, whereas it is about $80 \%$ in the city as a result of tightness of area cover.

The areas which have high level of tightness are, inter alia, surfaces of roads, squares, building roofs and rock outcrops with low cracking level. Mentioned infrastructure elements are made with gradients in order to force water flow from external areas, which is the basic condition improving durability and functionality of buildings in our climate. In forest areas, roads, less often squares with the function of timber yards, possibly buildings can be seen among other objects with high level of tightness.

Forest areas must be appropriately made available, so that it will be possible to use them in compliance with the provisions of the forest law (Ustawa o lasach 1991). Apart from the function of protecting waters, soils and air, creating the living environment for a vast number of plants and animals. The forest fulfils also other important functions: it is the place for producing the multi-functional material - wood and many other raw materials, valuable for industry and society; it is a reserved area; the place of work, the place for rest, recreation and education; the place for pursuing sport and active tourism. It also has functions related to state defence. Fulfilling many of these functions by forest is inseparably linked to the possibility of communication that is existence of the forest road network. Roads are treeless strips of land, without natural coverage, appropriately shaped in longitudinal and transverse directions, on which car traffic with particular characteristics is possible. Light traffic with low intensity level can take place on roads with ground surface, however traffic of heavy-load vehicles is possible only on roads equipped with surfaces of high load rating, made of adequate materials and what is important, in compliance with the technical requirements. Surface water flow is created as a result of rainfall on all road surfaces, which have been properly constructed and maintained, but also on these, which have ruts and are eroded (Martinez-Zavala et al. 2008).

The subject of this work is surface runoff created on forest roads in mountainous areas. The objective of this work is to describe the meaning of surface runoff occurring in mountainous forest areas by analysing results of area measurements and simulation calculations for the described area.

Formulated the hypothesis that the density of the road network is significant for the size of surface runoff forming in mountain forest.

\section{Materials and methods}

\subsection{Study area}

The measurements were made in the catchment area of Dupniański Stream in the Silesian Beskid mountains, Forestry Division of Wisła (Fig. 1). The complete characteristics of the catchment area are provided by Suliński (1997), the most important parameters have been provided below.

The catchment area is located in the zone of Carpathian climate, in the river basin of Olza, standard annual precipi- 


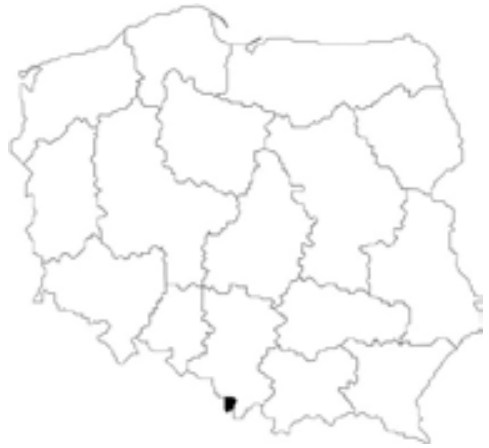

Figure 1. Location of Wisła Forestry Division

tation is $1200 \mathrm{~mm}$, average specific runoff in the long-term is $23 \mathrm{dm}^{3} \cdot \mathrm{s}^{-1} \cdot \mathrm{km}^{-2}$, average annual evapotranspiration is $515 \mathrm{~mm}$, average annual air temperature is $+5.5^{\circ} \mathrm{C}(\mathrm{Kli}-$ maszewski 1972; Stachý 1987). Catchment area is $1.68 \mathrm{~km}^{2}$, area ordinates $492.70 \mathrm{~m} \div 881.90 \mathrm{~m}$ above sea level, density of water network $3.64 \mathrm{~km} \cdot \mathrm{km}^{-2}$ (Czarniecka 1998).

The characteristics of selected sections of a slope road, on which measurements of surface runoff were conducted (Gołąb et al. 2006) is provided in the Table 2.

\subsection{Runoff measurements}

A single measurement section was indicated by installing two water culverts on the road surface. A culvert blocking water supply from the part of the road located above the surveyed section was installed in the upper part of the section, whereas a culvert placed below, collected the whole amount of water running off the surveyed section surface and it was equipped with a measuring container of about $25 \mathrm{dm}^{3}$. Measurement of the quantity of water collected by the measuring culvert was started every 15 minutes and lasted most frequently 5 minutes (with the precision of 1 s.) or the number of seconds was recorded, if the container filled in quicker. Water capacity was recorded with the precision of $0.1 \mathrm{dm}^{3}$. Water culverts were built and installed in the manner providing measurement of the whole runoff without any losses.

Precipitation was measured in two places: directly next to the road, on which runoff measurements were conducted and at the time of their performance, as well as in order to conduct other analyses (also of controlling purposes) at the flow area closing the catchment area. Precipitation at the road was measured every 15 minutes at the time of starting each measurement, however standard daily total quantity was recorded at the closing flow area.

Measurements were started on all sections at the same time and the obtained measurement results made it possible to compare measured values by calculating single runoff intensity - q', (in relation to $1 \mathrm{~m}^{2}$ ).

\subsection{Calculations conducted in the simulation of surface runoff from the network of forest roads}

Knowing the levels of the unit intensity of surface runoff from forest roads, simulation calculations can be conducted on the quantity of water runoff from a larger forest area, characterised by the existing or planned density of the road network. Such simulation is presented below.

Some preliminary assumptions should be made at the beginning of simulation calculations. It was assumed that

Table 2. Description of surveyed sections

\begin{tabular}{|c|c|c|c|c|c|}
\hline \multirow{2}{*}{\multicolumn{2}{|c|}{$\begin{array}{c}\text { Section description } \\
\text { A }\end{array}$}} & \multicolumn{4}{|c|}{ Section } \\
\hline & & $\mathrm{C}$ & $\mathrm{D}$ & $\mathrm{E}$ & \\
\hline \multicolumn{2}{|l|}{ Surface type } & \multicolumn{4}{|c|}{ ground with high amount of natural structure } \\
\hline Section length & {$[\mathrm{m}]$} & 37.10 & 60.40 & 43.95 & 54.10 \\
\hline Average width of carriageway & {$[\mathrm{m}]$} & 2.10 & 2.20 & 2.62 & 2.30 \\
\hline Road surface on a section & {$\left[\mathrm{m}^{2}\right]$} & 77.91 & 132.88 & 115.00 & 124.43 \\
\hline Ground filtration coefficient in the surface & {$\left[\mathrm{cm} \cdot \mathrm{min}^{-1}\right]$} & 0.003 & 0.000 & 0.000 & 0.004 \\
\hline Average section gradient & {$[\%]$} & 1.82 & 8.22 & 9.17 & 8.37 \\
\hline Presence of water effusion from a scarp & $(+),(-)$ & - & + & + & - \\
\hline Average height of a scarp trench & {$[\mathrm{m}]$} & 0.96 & 1.61 & 2.44 & 1.75 \\
\hline Average height of a scarp bank & {$[\mathrm{m}]$} & 0.45 & 0.65 & 0.87 & 0.38 \\
\hline Tree age & [years] & 55 & 50 & 80 & 80 \\
\hline Road cover with tree stand & {$[\%]$} & 70 & 30 & 30 & 40 \\
\hline
\end{tabular}


the conditions in which surface runoff was measured were average conditions in the simulation area. This applies to all area features, forest stand, roads, lands and precipitation. The assumed simulation area was 100 ha and runoff for two various densities of road networks were simulated: 15 and $25 \mathrm{~m} \cdot \mathrm{ha}^{-1}$. These values are from the range of the density of forest roads for the areas in the Carpathians recommended in the literature (Drogi leśne 2006). It was also assumed that the described precipitation cases lasted for 3 hours and simulations were conducted for-each of such periods.

Calculation of the water quantity in the surface runoff was based on the aforementioned measurements of the runoff intensity. For selected measurement sessions (15 September, 9 October and 16 October 2004 with precipitation: $9.8 \mathrm{~mm}, 5.2 \mathrm{~mm}$ and $2.8 \mathrm{~mm}$ and in the previously described session of 21 March 2004 without precipitation, during spring snowmelts), average single intensity was calculated, which was then calculated by the surface of roads (with the assumed average road width of $3 \mathrm{~m}$ ). Calculated quantities of surface runoff were also referred to the precipitation amount on the whole simulated area.

\section{Results}

\subsection{Quantity of surface runoff}

The results of measurements of the surface runoff intensity are presented below (Figs 2-4). They were conducted on selected road sections during three measurement sessions, different from each other in the precipitation level.

\subsection{Simulation of the runoff level from the network of forest roads}

The calculated average values of single intensity of the surface runoff were provided in Table 3 for different road sections and measurement sessions conducted during specific precipitation cases. Average values of single runoff intensities from all sections were also provided in Table 3 as representative values for the whole session and the whole area. These average values represented the basis for further simulation calculations.

Calculated quantities of the water coming from the surface runoff were provided in Table 4; the values are related to the surface of forest roads in the area of 100 ha at defined densities of the road network and assumptions defined in the chapter "Methodology". Moreover, the percentage of this runoff was compared with the general precipitation capacity.

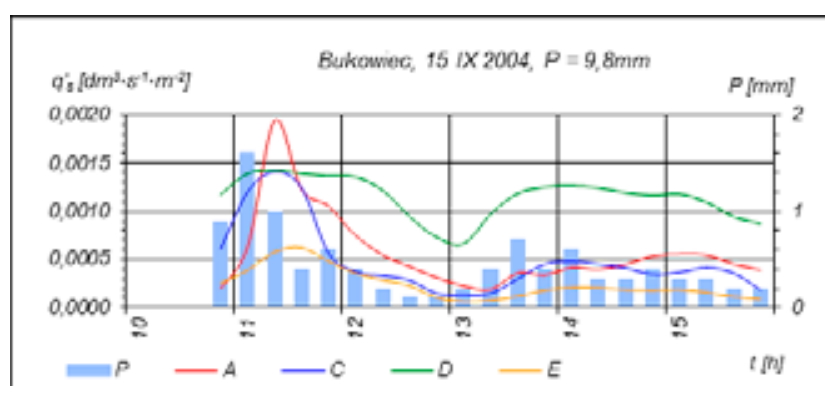

Figure 2. Intensity of surface runoff from sections of forest roads during the period of precipitation of $9.8 \mathrm{~mm}$

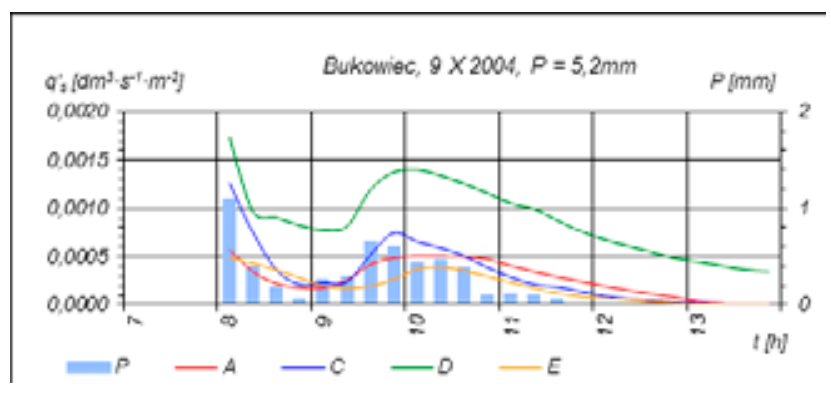

Figure 3. Intensity of surface runoff from sections of forest roads during the period of precipitation of $5.2 \mathrm{~mm}$

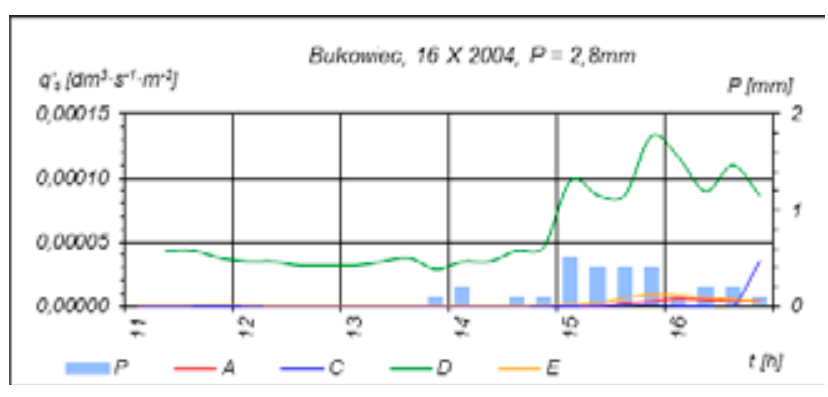

Figure 4. Intensity of surface runoff from sections of forest roads during the period of precipitation of $2.8 \mathrm{~mm}$

\section{Discussion and conclusions}

The data presented on the charts provides actual values of surface runoff of water from forest roads, whereas the applied measuring interval (15 minutes) shows the dynamics of this important ecological problem very well. The Figure 4 shows the starting point in the process of runoff forming at small cumulative precipitation. The interception phase of the initial precipitation through the forest hood was expressly shown as well as the surface of the road itself initial precipitation intensity was at the level between 0.1 $\div 0.2 \cdot 15 \mathrm{~min}^{-1}$ does not cause runoff creation, but only moistens the surface, was expressly provided. Small reaction took place only in the section $\mathrm{D}$, where the scarp 
Table 3. The average single surface runoff intensity from selected sections of forest roads

\begin{tabular}{|c|c|c|c|c|c|}
\hline \multirow{2}{*}{ Precipitation } & \multicolumn{4}{|c|}{ Road section } & \multirow{2}{*}{$\mathrm{q}_{\text {average }}^{\prime}$} \\
\hline & A & $\mathrm{C}$ & $\mathrm{D}$ & E & \\
\hline$[\mathrm{mm}]$ & \multicolumn{5}{|c|}{$\left[\mathrm{dm}^{3} \cdot \mathrm{s}^{-1} \cdot \mathrm{m}^{-2}\right]$} \\
\hline 2.8 & 0.0000042 & 0.0000094 & 0.0000599 & 0.0000023 & 0.00001899 \\
\hline 5.2 & 0.0002722 & 0.0003028 & 0.0008664 & 0.0001863 & 0.00040691 \\
\hline 9.8 & 0.0005561 & 0.0004879 & 0.0011126 & 0.0002333 & 0.00059750 \\
\hline $\begin{array}{l}\text { Spring snowmelt } \\
\text { (no precipitation) }\end{array}$ & 0.0002553 & 0.0016650 & 0.0068068 & 0.0006048 & 0.00233298 \\
\hline
\end{tabular}

Table 4. Quantity of water from surface runoff at different density of road network and the percentage of this runoff when compared to precipitation in the whole area

\begin{tabular}{|c|c|c|c|}
\hline \multirow{3}{*}{$\begin{array}{l}\text { Precipitation }(3 \mathrm{~h}) \\
{[\mathrm{mm}]}\end{array}$} & \multirow{3}{*}{$\begin{array}{c}\mathrm{q}_{\text {average }}^{\prime} \\
\text { from sections } \\
\mathrm{A}, \mathrm{C}, \mathrm{D} \text { and } \mathrm{E} \\
{\left[\mathrm{dm}^{3} \cdot \mathrm{s}^{-1} \cdot \mathrm{m}^{-2}\right]}\end{array}$} & \multicolumn{2}{|c|}{ Road density $\left[\mathrm{m} \cdot \mathrm{ha}^{-1}\right]$} \\
\hline & & 15 & 25 \\
\hline & & \multicolumn{2}{|c|}{$\begin{array}{l}\text { Water quantity in the runoff lasting } 3 \text { hours }\left[\mathbf{d m}^{3}\right] \\
\text { Surface runoff as \% of precipitation in the whole area of } 100 \text { ha }\end{array}$} \\
\hline 2.8 & 0.00001899 & $\begin{array}{l}923.1 \\
0.03 \%\end{array}$ & $\begin{array}{c}1538.4 \\
0.06 \%\end{array}$ \\
\hline 5.2 & 0.00040691 & $\begin{array}{c}19775.7 \\
0.38 \%\end{array}$ & $\begin{array}{c}32959.5 \\
0.63 \%\end{array}$ \\
\hline 9.8 & 0.00059750 & $\begin{array}{c}29038.4 \\
0.30 \%\end{array}$ & $\begin{array}{c}\mathbf{4 8} 397.4 \\
0.49 \%\end{array}$ \\
\hline $\begin{array}{c}\text { Spring snowmelt } \\
\text { (period of } 3 \mathrm{~h} \text {, no precipitation) }\end{array}$ & 0.00233298 & 113382.6 & 188971.1 \\
\hline
\end{tabular}

trench cross the canal of intra-layer runoff. After initial moistening of the surface and increasing precipitation intensity, runoff was observed on all surveyed sections, yet its single intensity is at low level. The section D reacted much stronger. Runoff intensities were presented in the Figures 2 and 3, which were obtained in other measurements with similar precipitation intensity. Runoff intensities obtained here are very similar, with a visible advantage gained in the section D. Both measuring sessions were started on time, when precipitation had already started, yet they showed changed in runoff quantities as the reaction on variations of precipitation and the lack of it (Fig. 3). A 30-minute delay was expressly shown, related to minimum and maximum runoff intensity in relation to minimum and maximum precipitation intensity. The dynamics of this reaction on individual road sections is related to individual features of these sections, which shall be the topic of separate research. Special attention should be paid to the intensity levels as well as the dynamics of changes (at least in the runoff initial phase), considerable impact on ground saturation with water coming from earlier precipitations
(Brodowski \& Rejman 2004). This type of materials and their analyses were included in other works (Gołąb 2011). Calculated runoff intensity levels on ground forest roads, with relatively low precipitation level, oscillating between $0.00001 \div 0.002 \mathrm{dm}^{3} \cdot \mathrm{s}^{-1} \cdot \mathrm{m}^{-2}$, in comparison to the average annual runoffs recorded by Midriak (1990) (Table 1) $-0.00000099 \mathrm{dm}^{3} \cdot \mathrm{s}^{-1} \cdot \mathrm{m}^{-2}$ on the yard or 0.00000055 and $0.00000009 \mathrm{dm}^{3} \cdot \mathrm{s}^{-1} \cdot \mathrm{m}^{-2}$ inside the forest and the data of Słupik (1972): $0.000167 \mathrm{dm}^{3} \cdot \mathrm{s}^{-1} \cdot \mathrm{m}^{-2}$ from the heavy rain inside the forest show the scale of the problem, which is the surface runoff on roads.

When taking these runoff intensities to the forest area of similar, assumed characteristics, the area of 100 ha, it was calculated that with the precipitation level of $2.8 \mathrm{~mm}$ lasting for 3 hours and the road density of $15 \mathrm{~m} \cdot \mathrm{ha}^{-1}$ : surface runoff will be created on roads, with the total value of $923.1 \mathrm{dm}^{3}$. It constitutes the average water consumption of one person for over ninety days (standard consumption level: $100 \mathrm{dm}^{3} \cdot$ day $^{-1} \cdot$ person $\left.^{-1}\right)($ Rozporządzenie Ministra Infrastruktury 2002). For the biggest precipitation level which was measured here of $9.8 \mathrm{~mm}$ and the network 
density of $25 \mathrm{~m} \cdot \mathrm{ha}^{-1}$, runoff was calculated at the level of $48397.4 \mathrm{dm}^{3}$, which constituted 484 times greater daily consumption (demand of one person for almost one and a half of year). For Spring snowmelts, for a 3-hour period without any precipitation and lower road network density, runoff level could obtain the 1134 times of the daily consumption (demand of one person for over three years), yet for the bigger surveyed network density: 1890 times of the daily consumption (demand of one person for over five years). However, these were the results of calculations performed for simulated conditions with many assumptions and averaging, yet their values have considerable meaning. It was supplemented and also in a way mediated the comparison of obtained runoff values with the general water quantity in this precipitation cases in the whole area (Table 4).

Based on the obtained results, the following conclusions have been drawn:

The presence of forest roads in the areas as well as other areas deprived of plants and with changed characteristics of filtration abilities in surface ground layers, decreases retention abilities of these areas.

Soil consolidation in road surfaces causes considerable change of filtration conditions in relation to the natural grounds and occurring surface runoff on roads, even at low precipitation levels, which has its consequences for the quickness of water circulation in nature.

The systems of surface dehydration and their elements applied in road constructions, especially water culverts, can effectively "regain" water from surface runoff, provided that water out flowing from these elements underground surface would be entered with care. A good solution seems to be installing modified absorbent wells just after the outlet of each of these devices.

A great significance for the amount of observed surface runoff from road surfaces has the fact of cutting the canal for intra-layer runoff with the scarp trench. Apart from the drainage effect of sometimes considerable area located above the road, greater erosive losses in road surfaces should be also expected.

The surface runoff level calculated in the simulation show one more time the significance of retention possibilities of the forest mountainous areas. It is especially important in the context of water deficit and the situation of the risk of flooding.

\section{References}

Bochenek W., 2002, Ocena możliwości retencyjnych pokryw glebowo-zwietrzelinowych na stoku pogórskim [Assessment of retention capacity of soil and debris covers on the piedmont slope], Regionalny Monitoring Środowiska Przyrodniczego, nr 3 [Regional Monitoring of Environment, No 3], Kieleckie Towarzystwo Naukowe, Kielce: 103-107.

Brodowski R. \& Rejman J., 2004, Określenie wpływu wilgotności i stanu powierzchni gleby wytworzonej z piasku gliniastego na spływ powierzchniowy i zmyw gleby [Determination of the effect of moisture content and surface conditions of soil developed from loamy sand on the surface runoff and rain-wash], Acta Agrophysica 4(3): 619-624.

Czarniecka A., 1998, Systemy informacji przestrzennej odwzorowanie wybranych elementów ekosystemu za pomocą atrybutowej bazy danych i cyfrowych map wektorowych, praca magisterska, maszynopis [Spatial information systems - mapping of selected elements of the ecosystem using attribute databases and digital vector maps, Master Thesis, manuscript], Wydział Elektrotechniki AGH, Kraków.

Drogi leśne. Poradnik techniczny [Forest roads. Technical Guide], 2006, Wydawnictwo Ośrodek Rozwojowo-Wdrożeniowy Lasów Państw., Bedoń.

Gil E., 1990, Racjonalne użytkowanie ziemi na stokach pod kątem ochrony przeciwpowodziowej i przeciwerozyjnej [Efficient use of soils on the slopes in terms of inundation and erosion control], Problemy Zagospodarowania Ziem Górskich 30: 31-48.

Gołąb J., 2004, Influence of forest slope road on water storage in adjoining soils, EJPAU, Ser. Forestry, www. ejpau.media.pl/series/volume7/issue2.

Gołąb J., 2011, Przechwytywanie wewnątrzgruntowego spływu wody przez wykop leśnej drogi stokowej [Capturing of the intraground flow of water by the forest slope road excavation], Infrastruktura i Ekologia Terenów Wiejskich 7: 179-188.

Gołąb J., Wańczyk R. \& Matusiak B., 2006, Surface runoff from slanting forest roads, Acta Scientiarum Polonorum Silvarum Colendarum Ratio et Industria Lignaria 5 (1): 13-25.

Gradkowski K., 2011, Kontrola spływu powierzchniowego wód z pasów drogowych, cz. 1 [Monitoring of surface runoff from roadways, part 1], Polski Instalator 1/2011: 63-67.

Klimaszewski M. (ed.), 1972, Geomorfologia Polski, tom. 1 Polska Południowa. Góry i wyżyny [Geomorphology of Poland, vol. 1 Southern Poland. Mountains and uplands] PWN, Warszawa.

Kosturkiewicz A. \& Szafrański C., 1983, Spływy powierzchniowe i podpowierzchniowe w bilansie wodnym gleb [Surface and subsurface runoff in the soil water balance], Prace Komisji Nauk Rolniczych i Komisji Nauk Leśnych PTPN 55: 127-144.

Martínez-Zavala L., Jordán López A. \& Bellinfante N., 2008. Seasonal variability of runoff and soil loss on forest road backslopes under simulated rainfall, Catena 74: 73-79. 
Midriak R., 1990, Povrchovy odtok a podne straty vo vysokohorskych ekosystemach, Ved. Pr., VULH 39: 57-78.

Rozporządzenie Ministra Infrastruktury z dnia 14 stycznia 2002 r. w sprawie określenia przeciętnych norm zużycia wody, [Regulation of the Ministry of Infrastructure of January 14, 2002 on the determination of average water consumption standards], Dziennik Ustaw nr 8 z dnia 31 stycznia 2002 r., Poz. 70 [Journal of Laws No. 8 of January 31, 2002, item 70], Warsaw.

Słupik J., 1972, Spływ powierzchniowy na stokach górskich Karpat fliszowych [Surface runoff from slopes of the Flysch Carpathian mountains], Gospodarka Wodna [Water Management] 8: 290-295.

Stachý J., 1987, Atlas hydrologiczny Polski. t I [Hydrological atlas of Poland, vol. 1], Wydawnictwo Geologiczne, Warszawa.
Suliński J. (ed.), 1997, Sprawozdanie z prac wykonanych w I etapie badań "Zbadanie bilansu wodnego świerczyn rasy istebniańskiej", maszynopis [Report on the work completed in the 1st stage of the study "Assessment of the water balance of the Istebna spruce variety", manuscript], Zakład Inżynierii Leśnej, Akademii Rolniczej, Kraków.

Ustawa o lasach, 1991, tekst ujednolicony [Forest Act, 1991, standardized text], Dziennik Ustaw z $2011 \mathrm{nr} 12$ poz. 59 [Journal of Laws No 12 of 2011, item 59], Warszawa.

Wemple B. C. \& Jones J. A., 2003, Runoff production on forest roads in a steep, mountain catchment, Water Resources Research 39(8): 1220, doi:10.1029/2002WR001744. 